УДК 159.9.019.4:001.8(045)

DOI https://doi.org/10.26661/2310-4368/2021-1-12

\title{
АВТОРСЬКИЙ ОПИТУВАЛЬНИК «ШКАЛИ МУЛЬТИКУЛЬТУРНОЇ ІДЕНТИФІКАЦЇ̈»: ПРОЦЕС КОНСТРУЮВАННЯ ТА ОПИС ПРОДУКТУ
}

\author{
Мамбетова А. A. \\ аспірант кафедри психологї̈ розвитку \\ факультету психології \\ Київський начіональний університет імені Тараса Шевченка \\ вул. Володимирська, 60, Київ, Україна \\ orcid.org/0000-0001-8586-5078 \\ arzy308@gmail.com
}

\begin{abstract}
Ключові слова:
мультикультурна

ідентифікація, авторський

психологічний опитувальник,

шкали мультикультурної

ідентифікації, культурні

уклади, етнокультурні

психологічні особливості.
\end{abstract}

У статті подано опис авторського опитувальника, що грунтується на основі припущення про те, що люди мають відмінні стилі сприймання навколишньої дійсності та реагування на неї, які створюють основу для різних культурних укладів. Проведення мультикультурної ідентифікації та визначення типового культурного укладу для представників певного етносу дає змогу більш предметно розуміти їхні характеристики ментальності та інші психологічні особливості.

Головним завданням цієї роботи є створення психодіагностичної методики для визначення приналежності представників різних етносів до того чи іншого культурного укладу (проведення мультикультурної ідентифікаціі). Культурний уклад - поняття, що характеризує історично сталі стійкі типові риси порядку побудови та змістовної наповненості нормативно-ціннісних конструктів, які притаманні соціальним групам та індивідам і виражені у матеріальних, ідеальних організаційних та символічних компонентах їх індивідуального та групового життя в умовах конкретного суспільства.

Мета статті - презентувати авторський опитувальник «Шкали мультикультурної ідентифікації», що покликаний надати додаткові можливості для більш глибокого вивчення науковоїпроблематики культурних укладів та їхнього взаємозв'язку із психологічними особливостями особистості в етнокультурному контексті.

У процесі теоретичного огляду проблематики поняття мультикультурної ідентифікації було описано теоретичну базу для конструювання методики, виокремлено основні завдання та обгрунтовано доцільність створення даної методики. Під час практичної роботи була сконструйована методика для дослідження ідентифікації респондентів - представників певних етносів 3 певними культурними укладами; перевірена ii надійність і валідність, що дає підстави для використання цього опитувальника як діагностичного інструменту. Проте інтерпретація результатів передбачає наявність спеціалізованих знань в області психології розвитку та етнокультурної психології. Тому цю методику краще використовувати психологам, але можливе і використання не спеціалістами при попередній підготовці. 


\title{
AUTHOR'S MULTICULTURAL IDENTIFICATION SCALE QUESTIONNAIRE: DESIGN PROCESS AND PRODUCT DESCRIPTION
}

\author{
Mambetova A. A. \\ Postgraduate Student at the Department of Developmental Psychology \\ of the Faculty of Psychology \\ Taras Shevchenko National University of Kyiv \\ Volodymyrska str., 60, Kyiv, Ukraine \\ orcid.org/0000-0001-8586-5078 \\ arzy308@gmail.com
}

\begin{abstract}
Key words: multicultural identification, author's psychological questionnaire, multicultural identification scales, cultural modes, ethnocultural psychological features.
\end{abstract}

\begin{abstract}
The article describes the author's questionnaire, which is based on the assumption that people have different styles of perceiving and responding to the surrounding reality, which in turn form the basis of different cultural systems. Carrying out multicultural identification and determining a typical cultural structure for members of a particular ethnic group allows a more objective understanding of their mental characteristics and other psychological characteristics.

The main task of this work is to create a psychodiagnostic method for determining the affiliation of representatives of different ethnic groups to a particular cultural system (conducting multicultural identification). Cultural structure is a concept that characterizes historically stable typical features of the order of construction and content of normative-value constructs, which are inherent in social groups and individuals and are expressed in material, ideal organizational and symbolic components of their individual and group life in a particular society.

The purpose of the article is to present the author's questionnaire "Multicultural Identification Scales", which is designed to provide additional opportunities for a deeper study of the scientific issues of cultural systems and their relationship with the psychological characteristics of the individual in the ethnocultural context. In the process of theoretical review of the concept of multicultural identification, the theoretical basis for the construction of the method was described, the main tasks were identified and the expediency of creating this method was substantiated. During the practical work a methodology was constructed to study the identification of respondents - representatives of certain ethnic groups with certain cultural backgrounds; its reliability and validity are checked, which gives grounds for using this questionnaire as a diagnostic tool. However, the interpretation of the results implies the presence of specialized knowledge in the field of developmental psychology and ethnocultural psychology. Therefore, this technique is better to use psychologists, but it is possible to use non-specialists in preliminary training.
\end{abstract}

Постановка проблеми. Кожне суспільство на основі притаманних йому інституційних вимог і принципів побудови процесів соціалізації особистості висуває до неї конкретні вимоги і надає певні ресурси, щоб особистість могла соціалізуватися відповідно до них. Соціальні трансформації, серед іншого, призводять до змін як змістовного складника соціалізації, так і до трансформації самих іiі механізмів. Соціалізація відбувається на основі певних культурних укладів, які надають абстрактно-логічні та чуттєво-образні тлумачення тому, що відбувається з людиною на різних етапах iii життя. Ці культурні коди значною мірою визначають характер формування психоемоційного складника у життєдіяльності людини, впливають на основу iï ціннісних орієнтацій у життєвому середовищі та уявлень про необхідні форми поведінки.

У процесі соціальних трансформацій, які переживає сучасне українське суспільство, відбуваються докорінні зміни у свідомості людей, переоцінка цінностей, відкидання застарілих ідеалів та побудова нових систем цінностей. Зокрема, суспільство як середовище соціалізації стає більш культурно різноманітним: актуалізуються сегменти культури, які ще донедавна вважилися архаїчними, виникають новітні утворення, значно розширюється присутність світових культур у 
середовищі масового спілкування. Це створює як додаткові можливості, так і нові ризики й загрози формуванню особистості людини.

Мета статті - презентувати авторський опитувальник «Шкали мультикультурної ідентифікації», що покликаний надати додаткові можливості для більш глибокого вивчення наукової проблематики культурних укладів та їхнього взаємозв'язку iз психологічними особливостями особистості в етнокультурному контексті.

Виклад основного матеріалу.

Мультикультурна ідентифікація - теоретичне узагальнення. Проблеми комплексного розвитку особистості та ії цілісності складають міжпредметну галузь досліджень, різні аспекти якої досліджують філософи, соціологи, психологи, культурологи та педагоги. У вітчизняній філософії проблеми соціалізації особистості знайшли своє втілення у роботах I.I. Кального, А.О. Ручки, В.Г. Табачковського, О.Д. Шоркіна, Ю.Д. Парунової [1;3].

У педагогічній науці на сучасному етапі проблема соціалізації особистості вирішується в контексті особистісно-орієнтованої освіти, витоки якої знаходимо в роботах К. Роджерса. До цього напряму належать дослідження С.В. Бондаревської, А.І. Ковальової, О.В. Мудрика, А.В. Петровського [2; 4]. Соціологія розглядає зазначену проблематику здебільшого в межах «розуміючої соціології» та структурного функціоналізму. У роботах М. Вебера, Е. Дюркгайма, Р. Мертона, T. Парсонса розглядаються різні аспекти особистості як об'єкта соціалізації [5].

Проблеми співвідношення соціалізації та індивідуалізації цікавлять Ф. Гіденса, Г. Зіммеля. Ця ж проблема піднімається й у символічному інтеракціонізмі Дж. Міда та теорії «дзеркального Я» Ч. Кулі, у феноменологічній соціології П. Бергера, T. Лукмана, А. Шюца, які наполягають на тому, що особистість - це суб'єкт соціалізації [6]. Етапи соціалізації розглядає Г. Тард.

Сучасна соціологія здебільшого звертається до осмислення соціалізації особистості в умовах формування інформаційного суспільства. Це дослідження Д. Белла, 3. Баумана, Н. Смелзера, O. Тоффлера, на пострадянському просторі І.Ю. Кисельова, В.В. Малахова, В.О. Матусевич, К.Г. М'яло, Н.М. Федотової, В.Г. Полохала, І.М. Попової, І.М. Растової, А.Г. Смирнової, Т.В. Хрієнко, В.А. Ядова [7].

У рамках своєї предметної царини психологія розглядає проблему соціалізації як процес впливу на психіку людини. Цією проблематикою переймаються майже всі школи, що розробляють теорію особистості: фрейдизм, біхевіоризм, гештальтпсихологія. У наш час впливовими напрямами в цій галузі $\epsilon$ феноменологічний і когнітивний, які тлумачать активність людини як вияв її творчої природи. На думку представників цих напрямів (К. Роджерс, Х. Теджфел), людина засвоює в процесі соціальної взаємодії лише те, що сприяє iii самоактуалізації [8]. Варто також відзначити роботи Е. Еріксона, який зробив значний внесок у розробку концепції ідентичності.

У радянській i пострадянській психології проблеми соціалізації досліджувалися у роботах В.С. Агєєва, Г.М. Андрєєвої, О.Г. Асмолова, Л.С. Виготського, І.С. Кона, К.В. Коростеліної $[2 ; 5]$. Вітчизняний науковий доробок складають праці, авторами яких є С.Д. Максименко, I.B. Ващенко, О.І. Власова, С.Ю. Пащенко, Л.Г. Терлецька, І.В. Данилюк [1; 7]. Закордонна психологія розглядає проблеми соціалізації 3 позиції ії впливу на психіку людини взаємозв'язку в ній біологічного та соціального $[12 ; 13]$.

Цілісність особистості розглядається як аспект iii самоактуалізації та конструювання ідентичностей $[11 ; 14 ; 15]$. Однак концепції соціалізації особистості розвивалися в умовах суспільного порядку, який останнім часом зазнав значних історичних змін. Зокрема, одноукладність та одномірність суспільства змінилася його багатомірністю, закритість і сталість соціальних процесів - відкритістю та динамічністю. Суспільство як середовище соціалізації стало більш динамічним і різнонаправленим, постає перед особистістю все більше не як система вимог і можливостей, а як процес виникнення та актуалізації різних викликів і ризиків. За цих умов виникає низка методологічних проблем щодо того, як розуміти та досліджувати цілісність особистості та чи вона взагалі можлива за умов таких суспільних змін.

Культурний уклад - поняття, що характеризує історично сталі стійкі типові риси порядку побудови та змістовної наповненості нормативно-ціннісних конструктів, які притаманні соціальним групам та індивідам і виражені у матеріальних, ідеальних організаційних та символічних компонентах їх індивідуального та групового життя в умовах конкретного суспільства [7]. Культурний уклад $€$ конкретним історичним явищем, притаманним людській спільноті і характеризується принципами побудови, способами обміну діяльністю, матеріальною (технологічною) основою, типом цінностей і норм, соціально-історичною та просторово-часовою визначеністю. Розрізняють моноукладні та багатоукладні суспільства Україна належить саме до останніх. Залежно від способів суспільного виробництва культурологія виділяє типові культурні уклади: архаїчний, традиційний, модерновий і постмодерновий.

Традиційний культурний уклад характеризується виокремленою системою ціннісних уявлень, які концептуалізовані у вигляді міфологічних 
конструктів, що містять у собі абстрактно-особистісну детермінованість, а також наявністю централізованих систем нормотворчості. Соціальний актор формується у системі морально-етичного напруження між тим, як він повинен жити і як він живе відповідно до абстрактних уявлень про добро і зло, соціальне буття рефлексується як предмет утвердження власної благочесності. Самі під цим виміром формуються та здійснюються практично усі форми соціальної поведінки в рамках соціальних інститутів. Соціальний актор «відтворює справедливий стан речей відповідно до Істини» [4].

Модерновий культурний уклад характеризується опосередкованою колективністю, розподіленою системою концептуалізації ціннісних конструктів, що мають групову детермінованість, наявністю мультицентралізованої нормотворчості. Соціальний актор формується в контексті конструктивістського відношення до реальності - його ціннісні орієнтації $є$ суто прагматичним. Соціальний актор «змінює навколишній світ відповідно до спільних потреб людства» [5].

Постмодерновий характеризується мережевою формою колективної комунікативної ціннісної творчості та саморегулятивним характером нормативного регулювання. Соціальний актор формується у контексті комунікативних процесів, він $є$ завжди референтом реальності з точки зору реалізації індивідуального буття окремої людини. Соціальний актор «підключається» до процесів соціальної взаємодії, займаючи суто рефлексивну позицію [4; 5].

Культурні уклади визначають зміст і форми процесів соціалізації у конкретному суспільстві, що включає типи особистостей, рольові набори, рольові дистанції. В рамках культурних укладів формуються типи соціальних акторів та атрибути їх взаємодії. Залежно від власних парадигмальних установок дослідники розглядають культурний уклад або як один зі складників суспільного життя, що змінюється в процесі цивілізаційних змін, або як фундаментальний чинник цих змін, його рушійну силу.

3 точки зору наявності культурних укладів розрізняють моноукладні суспільства, у яких 3 необхідністю відтворюється лише один тип культурного укладу та багатоукладні суспільства, в яких із необхідністю відтворюються усі три типи культурних укладів. Багатоукладні суспільства можуть тяжіти до централізації та ієрархізації відносин між культурними укладами, а можуть мати відцентрові тенденції та рядопокладеність культурних укладів.

Культура сучасного українського суспільства 3 цієї точки зору є багатоукладною та характеризується відсутністю ієрархічних відносин між укладами, їх рядопокладеністю. Відтак норми і цінності, характерні для різних культурних укладів, співіснують одні поруч з іншими, утворюють симбіози або породжують суперечності у процесах соціалізації особистості. Наявність культурної багатоукладності $\epsilon$ характерною рисою середовища соціалізації в сучасній Україні. Це визначає необхідність дослідження типів становлення цілісної особистості саме крізь призму багатоукладності. Тому необхідно на основі потрактування цінностей в рамках того або іншого культурного укладу здійснити виділення відповідних типових рис різного роду цілісності, дослідження їх взаємодії між собою (див. табл. 1).

Основа розробленої методики. Сконструйований опитувальник грунтується на основі припущення про те, що люди мають відмінні стилі сприймання навколишньої дійсності та реагування на неї, які створюють основу для різних культурних укладів. Проведення мультикультурної ідентифікації та визначення типового культурного укладу для представників певного етносу дає змогу більш предметно розуміти їхні характеристики ментальності та інших психологічні особливості.

Головним завданням цієї роботи є створення психодіагностичної методики для визначення приналежності представників різних етносів до того чи іншого культурного укладу (проведення мультикультурної ідентифікаціі).

Інструкція до опитувальника. Люди мають відмінні стилі сприймання навколишньої дійсності та реагування на неї. Користуючись шкалою від 1 о 5, де 1 - точно незгодний, а 5 - повністю згодний, оцініть наскільки для вас прийнятні наведені нижче твердження. Відповідати потрібно швидко, довго не задумуючись.

Традиційний, Модерний. 1. У мене багато спільного 3 іншими представниками (певного народу).

Традиційний. 2. Відчуваю сильний зв'язок 3 іншими представниками свого етносу.

Модерний, Постмодерний. 3. Мені важко налагодити надійні зв'язки (контакти) з іншими представниками свого етносу.

Постмодерний. 4. Не відчуваю себе пов'язаним 3 іншими представниками свого етносу.

Традиційний. 5. Часто думаю про те, що я (представник певного етносу).

Постмодерний. 6. Загалом бути ... (кримським татарином/українцем) не має багато спільного 3 тим, ким я себе відчуваю (вважаю).

Традиційний, Модерний. 7. Загалом бути ... (кримським татарином/українцем) - важливий складник того, ким я $є$.

Постмодерний. 8. Правду кажучи, факт того, що я ..., (представник певного етносу) нечасто заповнює мої думки. 
Таблиця 1

Відмінності уявлень про складники суспільства відповідно до домінуючого типу культурного укладу, в якому вони соціалізуються

\begin{tabular}{|c|c|c|c|c|c|}
\hline $\begin{array}{c}\text { №№ } \\
\text { 3/II }\end{array}$ & Культурні уклади & $\begin{array}{c}\text { Базовий образ } \\
\text { суспільства } \\
\text { та соціальної } \\
\text { структури }\end{array}$ & $\begin{array}{c}\text { Соціально-психоло- } \\
\text { гічні ціннісні уяв- } \\
\text { лення соціальних } \\
\text { акторів }\end{array}$ & $\begin{array}{l}\text { Нормативні уяв- } \\
\text { лення соціаль- } \\
\text { них акторів }\end{array}$ & $\begin{array}{c}\text { Уявлення } \\
\text { щодо соціаль- } \\
\text { ної структури }\end{array}$ \\
\hline 11 & Традиційний & $\begin{array}{l}\text { Храм - спільнота } \\
\text { людей, об’єд- } \\
\text { наних єдиними } \\
\text { цінностями та } \\
\text { вірою }\end{array}$ & $\begin{array}{l}\text { Світ замкнений. } \\
\text { Основні цінності - } \\
\text { статичний порядок, } \\
\text { що походить від по- } \\
\text { залюдської інстанції }\end{array}$ & $\begin{array}{l}\text { Норма - те, що } \\
\text { відповідає ідеалу } \\
\text { справедливості та } \\
\text { добра }\end{array}$ & $\begin{array}{l}\text { Соціальна } \\
\text { структура - } \\
\text { продовження } \\
\text { природного } \\
\text { місця людини у } \\
\text { світі та історич- } \\
\text { них традицій }\end{array}$ \\
\hline 22 & Індустріальний & $\begin{array}{l}\text { Виробничий } \\
\text { конгломерат - } \\
\text { спільнота }\end{array}$ & $\begin{array}{l}\text { Світ недосконалий і } \\
\text { не відповідає потре- } \\
\text { бам людини. Основні } \\
\text { цінності - раціональ- } \\
\text { ний людиномірний } \\
\text { порядок групового } \\
\text { конструювання } \\
\end{array}$ & $\begin{array}{l}\text { Норма - те, що } \\
\text { відповідає потре- } \\
\text { бам людини }\end{array}$ & $\begin{array}{l}\text { Соціальна } \\
\text { структура - } \\
\text { умова реаліза- } \\
\text { ції здібностей і } \\
\text { можливостей у } \\
\text { суспільстві }\end{array}$ \\
\hline 33 & Постіндустріальний & $\begin{array}{l}\text { Мережевий про- } \\
\text { стір потокових } \\
\text { комунікацій між } \\
\text { окремими особи- } \\
\text { стостями }\end{array}$ & $\begin{array}{l}\text { Світ відкритий і } \\
\text { безмежно мінли- } \\
\text { вий. Основні цін- } \\
\text { ності - мінливість, } \\
\text { необов’язковість, } \\
\text { вільний безвідпові- } \\
\text { дальний доступ }\end{array}$ & $\begin{array}{l}\text { Норма - те, що } \\
\text { залежить від кон- } \\
\text { кретної ситуації } \\
\text { відносин між } \\
\text { людьми }\end{array}$ & $\begin{array}{l}\text { Соціальна } \\
\text { структура - не- } \\
\text { стійка потокова } \\
\text { мережа контак- } \\
\text { тів між людьми, } \\
\text { що постійно } \\
\text { змінюється }\end{array}$ \\
\hline
\end{tabular}

Традиційний, Модерний. 9. Загалом я задоволений тим, що я... (представник певного етносу).

Традиційний, П. Модерний. 10. Часто шкодую, що я ... (представник певного етносу).

Постмодерний. 11. Не почуваюся добре від того, що я ... (представник певного етносу).

Модерний. 12. Загалом почуваюся добре, коли думаю про себе як про... (представник певного етносу).

Традиційний. 13. Наше життя не залежить від нас. Воно підпорядковується іншим силам.

Постмодерний. 14. Ми повинні отримувати задоволення від кожного прожитого дня.

Традиційний. 15. Я буду робити так, як робили мої предки.

Модерний. 16. В житті потрібно прагнути розвиватися.

Постмодерний. 17. Мені байдуже як мене оцінять, якщо я роблю роботу, яка мені подобається.

Модерний. 18.Основа суспільства - це договір між окремими людьми.

Модерний. 19. Усі традиції повинні бути раціонально обгрунтовані.

Постмодерний. 20. Я робитиму так, як мені зручно, навіть якщо це не задовольняе потреб суспільства.

Традиційний. 21. Тільки разом ми можемо зберегти свою культуру.
Модерний. 22. Для того, щоб існувало суспільство, треба вміти домовлятися.

Традиційний. 23. Не бачу свого існування без свого етносу.

Постмодерний. 24. Мені все одно на думку інших людей.

Традиційний. 25. Я тотожний (на) до представників свого народу.

Модерний, Постмодерний. 26. Саморозвиток це основа нашого життя.

Ключі: За кожну відповідь, що співпадає 3 ключем, ставляться бали, відповідь - бал (див. табл. 2).

Таблиця 2

Підрахунок результатів

\begin{tabular}{|l|c|}
\hline Традиційний уклад & $\begin{array}{c}1,2,5,7,9,10,13,15,21, \\
23,25\end{array}$ \\
\hline Модерний уклад & $\begin{array}{c}1,3,7,9,10,12,16,18, \\
19,22,26\end{array}$ \\
\hline Постмодерний уклад & $\begin{array}{c}3,4,6,8,11,14,17,20, \\
24,26\end{array}$ \\
\hline
\end{tabular}

Шкали:

1. Ідентифікація з традиційним укладом.

2. Ідентифікація з модерним укладом.

3. Ідентифікація з постмодерним укладом.

Надійність тесту - це стійкість або узгодженість результатів тесту, які отримуються при повторному його використанні на тій же вибірці в 
різні моменти часу. Цей критерій дозволяє судити про те, чи можна довіряти результатам вказаного тесту і чи дійсно він вимірює те явище, для якого був розроблений.

Існує багато типів надійності тесту, але для нашої роботи ми обрали коефіцієнт надійності альфа Кронбаха (Cronbach's Alpha). Він дозволяє перевірити міру внутрішньої узгодженості тесту, тобто те, чи досліджується обране явище кожним із питань. Для обчислення цього коефіцієнту була використана програма SPSS.

Перевірка надійності. Отже, першопочатково тест складався 326 питань, при цьому альфа Кронбаха дорівнював 0,684 (сумнівна надійність внутрішньої узгодженості) (див. табл. 3).

Для підвищення показника внутрішньої узгодженості, базуючись на показниках колонки «Відкоригований пункт - сумарна кореляція», були виключені 3 опитувальника запитання, які мали від'ємні показники (5 питань):

22. Для того, щоб існувало суспільство, треба вміти домовлятися.

23. Не бачу свого існування без свого етносу.

24. Мені все дно на думку інших людей.

25. Я тотожний (на) до представників свого народу.

26. Саморозвиток - це основа нашого життя.

Після проведених маніпуляцій показник Альфа Кронбаха зріс до 0,720, що свідчить про прийнятну статистичну надійність внутрішньої узгодженості (див. табл. 4). Тобто, можна сказати, що ті 5 питань, які ми виключили, були не надійними та не узгодженими.

\section{Перевірка надійності}

Таблиця 3

\section{Статистика надійності}

\begin{tabular}{|c|c|}
\hline Альфа Кронбаха & $\begin{array}{c}\text { Кількість } \\
\text { пунктів }\end{array}$ \\
\hline, 684 & 26 \\
\hline
\end{tabular}

\begin{tabular}{|c|c|c|}
\hline & & Загальна статистика за \\
\hline $\begin{array}{l}\text { Поряд- } \\
\text { ковий } \\
\text { номер }\end{array}$ & $\begin{array}{c}\text { Середнє зна- } \\
\text { чення по шкалі, } \\
\text { якщо пункт }\end{array}$ & $\begin{array}{c}\text { Варіативність шкали, якщо } \\
\text { пункт видалено }\end{array}$ \\
\hline
\end{tabular}

Відкоригований

пункт - сумарна кореляція
Альфа Кронбаха, якщо пункт видалено

\begin{tabular}{|c|c|c|} 
питання & видалено & \\
\hline 1. & 49,05 & 74,123 \\
\hline 2. & 48,19 & 75,978 \\
\hline 3. & 49,05 & 74,148 \\
\hline 4. & 48,65 & 73,404 \\
\hline 5. & 48,47 & 73,777 \\
\hline
\end{tabular}

\begin{tabular}{|l|l|l|}
\hline 4. & 48,65 & 73,404 \\
\hline 5. & 48,47 & 73,777 \\
\hline 6. & 48,15 & 76,803 \\
\hline 7. & 49,05 & 75,573 \\
\hline
\end{tabular}

\begin{tabular}{|c|c|c|}
\hline 7. & 49,05 & 75, \\
\hline 8. & 48,46 & 75,7 \\
\hline 9. & 49,48 & 74,7 \\
\hline
\end{tabular}

10.

\begin{tabular}{l|l}
11. & 49,44 \\
\hline 12. & 49,43 \\
\hline
\end{tabular}

\begin{tabular}{|l|l|l|}
\hline 11. & 49,44 & 75,5 \\
\hline 12. & 49,43 & 78,5 \\
\hline 13. & 48,01 & 75,7 \\
\hline 15. & 49,17 & 76,1 \\
\hline
\end{tabular}

\begin{tabular}{|l|l|l|}
\hline 15. & 48,16 & 76,1 \\
\hline 16. & 48,74 & 76,3 \\
\hline 17. & 48,72 & 75,2 \\
\hline 18. & 48,86 & 71,9 \\
\hline
\end{tabular}

\begin{tabular}{|c|c|c|c|c|}
\hline 17. & 48,72 & 75,231 &, 197 &, 677 \\
\hline 18. & 48,86 & 71,944 &, 363 &, 665 \\
\hline 19. & 48,68 & 69,996 &, 531 &, 653 \\
\hline 20. & 48,11 & 76,950 &, 207 &, 679 \\
\hline 21. & 48,80 & 73,860 &, 263 &, 673 \\
\hline 22. & 48,01 & 78,587 &,- 196 &, 684 \\
\hline 23. & 48,84 & 73,111 &,- 295 &, 670 \\
\hline 24. & 49,06 & 77,559 &,- 020 &, 689 \\
\hline 25. & 48,53 & 76,302 &,- 112 &, 683 \\
\hline 26. & 48,54 & 74,701 &,- 260 &, 674 \\
\hline
\end{tabular}


Таблиця 4

Повторна перевірка надійності

Статистика надійності

\begin{tabular}{|c|c|}
\hline Альфа Кронбаха & $\begin{array}{c}\text { Кількість пунк- } \\
\text { тів }\end{array}$ \\
\hline, 720 & 21 \\
\hline
\end{tabular}

Загальна статистика за елементами

\begin{tabular}{|c|c|c|c|c|}
\hline $\begin{array}{c}\text { Порядко- } \\
\text { вий номер } \\
\text { питання }\end{array}$ & $\begin{array}{c}\text { Середне зна- } \\
\text { чкня по шкалі, } \\
\text { видалено }\end{array}$ & $\begin{array}{c}\text { Варіативність } \\
\text { шкали, якщо пункт } \\
\text { видалено }\end{array}$ & $\begin{array}{c}\text { Відкоригований } \\
\text { пунт - сумарна } \\
\text { кореляція }\end{array}$ & $\begin{array}{c}\text { Альфа Кронбаха, } \\
\text { якщо пункт видалено }\end{array}$ \\
\hline 1. & 36,70 & 60,261 &, 241 &, 713 \\
\hline 2. & 35,84 & 62,111 &, 274 &, 713 \\
\hline 3. & 36,70 & 60,711 &, 260 &, 712 \\
\hline 4. & 36,31 & 60,466 &, 315 &, 708 \\
\hline 5. & 36,12 & 60,060 &, 174 &, 717 \\
\hline 6. & 35,80 & 63,235 &, 351 &, 706 \\
\hline 7. & 36,11 & 60,050 &, 136 &, 720 \\
\hline 8. & 37,14 & 62,194 &, 101 &, 717 \\
\hline 9. & 36,42 & 62,272 &, 167 &, 708 \\
\hline 10. & 37,10 & 62,390 &, 319 &, 714 \\
\hline 11. & 37,09 & 59,830 &, 239 &, 719 \\
\hline 12. & 35,81 & 62,478 &, 158 &, 718 \\
\hline 13. & 36,40 & 61,617 &, 161 &, 706 \\
\hline 14. & 36,37 & 62,086 &, 338 &, 693 \\
\hline 15. & 36,52 & 59,003 &, 513 &, 719 \\
\hline 16. & 36,33 & 57,150 &, 135 &, 706 \\
\hline 17. & 35,77 & 63,707 &, 335 &, 710 \\
\hline 18. & 36,46 & 59,451 &, 283 &, 710 \\
\hline 19. & 36,49 & 59,878 &, 299 & \\
\hline 20. & 36,19 & 61,978 & & \\
\hline 21. & 36,20 & 60,735 & & \\
\hline
\end{tabular}

Валідність тесту. Валідність методики поняття, яке вказує, що тест вимірює і наскільки добре він це робить. Вона за своєю суттю - комплексна характеристика, що включає відомості про те, чи придатна методика для вимірювання того, для чого вона була створена, яка їі дієвість, ефективність, практична корисність.

Тест називається валідним, якщо він вимірює те, для вимірювання чого призначений. У ході дослідження ми використовували конкурентну валідність. Конкурентна (поточна) валідність - це ступінь кореляції балів, що валідизується з іншими змінними, виміряними одночасно $з$ проведенням основного тесту.

У рамках нашого дослідження ми порівняли нашу методику 3 методикою «Тривимірна оцінка сили групової ідентифікації» Дж. Кемерона [9; 10]. Це дало можливість зробити висновок про те, що обидві методики вимірюють одне й те ж явище. Важливо, що коефіцієнт валідності виявився помірним, адже якщо б він був високим, це свідчило б про те, що наша методика повністю дублює вже існуючу і тоді сенсу в їі конструюванні немає (див. табл. 5).

Отже, як видно 3 таблиці, кореляція $є$ помірною.

Інтерпретація результатів. Результати діагностики мультикультурної ідентифікації представників певного етносу дають змогу визначити домінуючий для них уклад (домінуючу шкалу, що характеризується особливим набором цінностей $\mathrm{i}$ смисложиттєвих орієнтацій) за такими шкалами:

1. Ідентифікація з традииійним укладом. Відповідно до традиційного способу життя цінності розглядаються незалежно від людей і суспільства й даються зовнішніми силами (Бог, природа). Це життєвий обов'язок, з яким людина може зіткнутися в реальному житті.

У традиційних суспільствах соціальні інститути так чи інакше підпорядковуються відносинам між поколіннями. Тобто, люди похилого віку мають більше матеріальних ресурсів, організаційного впливу та культурного контролю над молодим поколінням. 
Перевірка валідності

Таблиця кореляцій основних характеристик порівнюваних методик

\begin{tabular}{|c|c|c|c|c|c|}
\hline \multirow{2}{*}{$\begin{array}{l}\text { Основні харак- } \\
\text { теристик автор- } \\
\text { ської методики } \\
\text { Дж. Кемерона }\end{array}$} & \multirow[b]{2}{*}{$\begin{array}{l}\text { Показники } \\
\text { кореляції }\end{array}$} & \multicolumn{4}{|c|}{ Основні характеристик авторської методики } \\
\hline & & $\begin{array}{c}\text { схильність до } \\
\text { ризику } 1\end{array}$ & $\begin{array}{c}\text { схильність до } \\
\text { ризику } 2\end{array}$ & шкала брехні 1 & шкала брехні 2 \\
\hline \multirow{3}{*}{$\begin{array}{l}\text { схильність до } \\
\text { ризику } 1\end{array}$} & $\begin{array}{c}\text { Кореляція Пір- } \\
\text { сона }\end{array}$ & & ,433* & & \\
\hline & Sig. (2-tailed) & &, 017 & & \\
\hline & $\mathrm{N}$ & & 81 & & \\
\hline \multirow{3}{*}{$\begin{array}{l}\text { схильність до } \\
\text { ризику } 2\end{array}$} & $\begin{array}{c}\text { Pearson } \\
\text { Correlation }\end{array}$ & ,433* & & & \\
\hline & Sig. (2-tailed) & 017 & & & \\
\hline & $\mathrm{N}$ & 81 & & & \\
\hline \multirow{3}{*}{ шкала брехні 1} & $\begin{array}{c}\text { Pearson } \\
\text { Correlation }\end{array}$ & & & &, $438 * *$ \\
\hline & Sig. (2-tailed) & & & & ,000 \\
\hline & $\mathrm{N}$ & & & & 81 \\
\hline \multirow{3}{*}{ шкала брехні 2} & $\begin{array}{c}\text { Pearson } \\
\text { Correlation }\end{array}$ & & &, $438 * *$ & \\
\hline & Sig. (2-tailed) & & & 000 & \\
\hline & $\mathrm{N}$ & & & 81 & \\
\hline
\end{tabular}

*. Кореляція є значимою на рівні 0,05 (двостороння).**. Кореляція є значимою на рівні 0,01 (двостороння).

2. Ідентифікачія з модерним укладом. Модерновий культурний спосіб життя характеризується соціальною взаємодією через діяльність, зокрема спільною діяльністю, спрямованою на зміну умов життя, раціональне продукування загальнолюдських структур цінностей і створення спільних правил. Тут суспільство розуміється як єдина ситуація спільної діяльності, а також як необхідний інструмент, який люди самі розробляють у зв'язку із задоволенням своїх потреб і реалізацією власних суттєвих характеристик.

3. Ідентифікачія із постмодерним укладом. Постмодерна культурна структура формується на основі соціальної взаємодії та на основі відкритої комунікації (створення спільного ситуативного простору) у вигляді мережі, відсутності інституціоналізованої системи регулювання цінностей і символічної самоідентифікації. Характеризується персоналізованою спільнотою самореференцій. Культура і суспільство розуміються як умови міжособистісного спілкування в системі, метою якого є самореалізація індивідів. Постмодерністське тлумачення передбачає розуміння цінностей як інструменту гри з метою отримання задоволення від взаємодії у різних сферах життя. У цьому випадку вони відносні, контекстуальні, орієнтовані на стан індивіда i процеси комунікації.

Висновки. У процесі теоретичного огляду проблематики поняття мультикультурної ідентифікації було описано теоретичну базу для конструю- вання методики, виокремлено основні завдання та обгрунтовано доцільність створення цієї методики. Під час практичної роботи була сконструйована методика для дослідження ідентифікації респондентів - представників певних етносів із певними культурними укладами; перевірена іiі надійність і валідність, що дає підстави для використання цього опитувальника як діагностичного інструменту.

Перевірка надійності опитувальника була здійснена таким чином: першопочатково тест складався із 26 питань, при цьому коефіцієнт альфа Кронбаха дорівнював 0,684, що ідентифікувало сумнівну надійність внутрішньої узгодженості. Для підвищення показника внутрішньої узгодженості 3 опитувальника були виключені запитання, які мали від'ємні показники сумарної кореляції. Це дозволило визнати прийнятну статистичну надійність внутрішньої узгодженості опитувальника (коефіцієнт альфа Кронбаха зріс до 0,720). Перевірка надійності опитувальника була здійснена таким чином: характеристики розробленої методики було порівняно з характеристиками тематично близької методики «Тривимірна оцінка сили групової ідентифікації» Дж. Кемерона. Це дало можливість зробити висновок про те, що обидві методики вимірюють одне й те ж явище. Важливо, що коефіцієнт валідності виявився помірним, адже якщо б він був високим, це свідчило б про те, що розроблена методика значною мірою дублює 
вже існуючу методику Дж. Кемерона і тоді сенсу в її конструюванні не було б.

Проте інтерпретація результатів передбачає наявність спеціалізованих знань в області психо- логії розвитку та етнокультурної психології. Тому таку методику краще використовувати психологам, але можливе і використання не спеціалістами при попередній підготовці.

\section{ЛІТЕРАТУРА}

1. Ananova I.V., Vlasova O.I., Hulenko A.S., Danyliuk I.V., Fadieieva K.-M., Shcherbyna V.L. The types of personal integrity of the modern Ukrainian multicultural society. Socio-economic sciences and challenges of modern technology and planetary communication: International Conference on ICT Management for Global Competitiveness and Economic Growth in Emerging Economies ICTM 2015. http://papers.ssrn.com Retrieved from URL: http://papers.ssrn.com/sol3/cf_dev/AbsByAuth.cfm?per_ $\mathrm{id}=2469326$.

2. Bulatevich N., Mambetova A. Psychological peculiarities of parenthood apprehensions of Ukrainians and Crimean Tartars. International Journal of Education \& Development. 2018. № 1. P. 13-24.

3. Ryan R., Deci E. Self-detenrrination theory and the facilitation of intrinsic motivation, social development, and well-being. American Psychology. 2000. Vol. 55(1). P. 68-78.

4. Ryff C.D., Keyes C.L.M. The structure of psychological well-being revisited. Journal of Personality and Social Psychology. 1995. № 69. P. 719-727.

5. Ryff C.D., Singer B. Human health: new directions for the next millennium. Psychological Inquiry. 1998. № 9. P. 69-85.

6. Shykovets S.O., Mambetova A.A. Psychological features of the representatives' identity in the regional communitiesof Ukraine and Poland. Науковий Вісник Херсонського державного університету. Психологія. 2018. № 3.1. С. 142-148.

7. Vlasova O.I. Influence of internet dependency on young people self-actualization. Socialization \& Human Development: International Scientific Journal. 2019. №1. 1. P. 5-12.

8. Boatswain S., Lalonde R. Social identity and preferred ethnic/racial labels for blacks in Canada. Journal of Black Psycholog. 2000. 26. P. 216-234.

9. Cameron J. A three factor model of social identity. Self and Identity. 2004.

10. Cameron J., Lalonde R. Social identification and gender related ideology in women and men. British Journal of Social Psychology. 2001. 40. P. 59-77.

11. Bichler S., Albert I., Barros S. et al. Exploring Cultural Identity in a Multicultural Context - the Special Case of Luxembourg. Hu Arenas. 2020. № 3. P. 310-330. https://doi.org/10.1007/s42087-019-00090-w.

12. Berry J.W. Theories and models of acculturation. In S.J. Schwartz \& J. B. Unger (Eds.). Oxford library of psychology. The Oxford handbook of acculturation and health. New York : Oxford University Press. 2017. P. $15-28$.

13. Goedert C., Albert I., Barros S., Ferring D. Welcome or not? - Natives' security feelings, attachment and attitudes toward acculturation of immigrants. International Journal of Intercultural Relations. 2019. 69. P. 24-31. https://doi.org/10.1016/j.ijintrel.2018.12.001.

14. Barros S, Albert I. I feel more Luxembourgish, but Portuguese too. Cultural Identities in a Multicultural Society. Integrative Psychological and Behavioral Science. First Online. 2019. P. 1-32. https://doi.org/10.1007/s12124-019-09500-8.

15. Mangum M., Block R. Social identity theory and public opinion towards immigration. Social Sciences. 2018. 7(3). 41 p. https://doi.org/10.3390/socsci7030041.

\section{REFERENCES}

1. Ananova I.V., Vlasova O.I., Hulenko A.S., Danyliuk I.V., Fadieieva K.-M., Shcherbyna V.L. (2015) The types of personal integrity of the modern Ukrainian multicultural society Socio-economic sciences and challenges of modern technology and planetary communication: International Conference on ICT Management for Global Competitiveness and Economic Growth in Emerging Economies ICTM 2015: http://papers.ssrn.com Retrieved from URL: http://papers.ssrn.com/sol3/cf_dev/AbsByAuth.cfm?per_ $\mathrm{id}=2469326$.

2. Bulatevich N., Mambetova A. (2018). Psychological peculiarities of parenthood apprehensions of Ukrainians and Crimean Tartars. International Journal of Education \& Development, 1. P. 13-24.

3. Ryan R., Deci E. (2000). Self-detenrrination theory and the facilitation of intrinsic motivation, social development, and well-being. American Psychology. Vol. 55 (1). P. 68-78.

4. Ryff C.D., Keyes C.L.M. The structure of psychological well-being revisited // Journal of Personality and Social Psychology, 1995, № 69. P. 719-727. 
5. Ryff C.D., Singer B. Human health: new directions for the next millennium // Psychological Inquiry, 1998, № 9. P. 69-85.

6. Shykovets S.O., Mambetova A.A. (2018). Psychological features of the representatives' identity in the regional communitiesof Ukraine and Poland. Naukovyi Visnyk Khersonskoho Derzhavnoho Universytetu. Psykholohiia - Scientific Bulletin of Kherson State University. Psychology, 3, 1. P. 142-148.

7. Vlasova O.I. (2019). Influence of internet dependency on young people self-actualization. Socialization \& Human Development: International Scientific Journal, 1, 1. P. 5-12.

8. Boatswain S., Lalonde R. (2000). Social identity and preferred ethnic/racial labels for blacks in Canada. Journal of Black Psychology, 26. P. 216-234.

9. Cameron J. (2004). A three factor model of social identity. Self and Identity.

10. Cameron J., Lalonde R. (2001). Social identification and gender related ideology in women and men. British Journal of Social Psychology, 40. P. 59-77.

11. Bichler S., Albert I., Barros S. et al. (2020). Exploring Cultural Identity in a Multicultural Contex - the Special Case of Luxembourg. Hu Arenas 3. 310-330. https://doi.org/10.1007/s42087-019-00090-w.

12. Berry J.W. (2017). Theories and models of acculturation. In S.J. Schwartz \& J.B. Unger (Eds.), Oxford library of psychology. The Oxford handbook of acculturation and health (p. 15-28). New York : Oxford University Press.

13. Goedert C., Albert I., Barros S., Ferring D. (2019). Welcome or not? - Natives' security feelings, attachment and attitudes toward acculturation of immigrants. International Journal of Intercultural Relations, 69, 24-31. https://doi.org/10.1016/j.ijintrel.2018.12.001.

14. Barros S., Albert I. (2019). I feel more Luxembourgish, but Portuguese too. Cultural Identities in a Multicultural Society. Integrative Psychological and Behavioral Science. First Online. P. 1-32. https://doi.org/10.1007/s12124-019-09500-8.

15. Mangum M., Block R. (2018). Social identity theory and public opinion towards immigration. Social Sciences, 7(3), 41. https://doi.org/10.3390/socsci7030041. 